\title{
18. THE GEOLOGY OF PETER I ISLAND
}

\author{
Thomas W. Bastien, Ernest K. Lehmann \& Associates, Inc., Minneapolis, Minnesota \\ and \\ Campbell Craddock, University of Wisconsin, Madison, Wisconsin
}

\section{INTRODUCTION}

Peter I Island is located in the southeastern Pacific Ocean at $68^{\circ} 45^{\prime} \mathrm{S}, 90^{\circ} 40^{\prime} \mathrm{W}$, approximately $240 \mathrm{n}$.mi. off the Eights Coast of West Antarctica (Figure 1). Rising from the upper continental rise, it is one of the few truly oceanic islands in the southeast quadrant of the Pacific Ocean. Few people have visited the island, and little is known of its geology.

Peter I Island was discovered by Captain Thaddeus (or Fabian Gotliev) von Bellingshausen the afternoon of 10 January 1821, while commanding the Russian sloops Vostok and Mirny (U.S. Navy Hydrographic Office, 1960); his approach from the west was stopped by pack ice about $14 \mathrm{mi}$ from the island. This discovery was the first sighting of land south of the Antarctic Circle (Debenham, 1945). On 14 January 1910, the Pourquoi-Pas?, commanded by Dr. Jean Charcot, sailed within $3 \mathrm{mi}$ of the island but also encountered pack ice; this second sighting of the island was the first confirmation of its existence. The Norwegian vessel Odd I circumnavigated the island in January 1927; they were unable to land, but dredge hauls provided specimens for the petrographic study of Broch (1927). In February 1929, Nils Larsen, captain of the Norvegia, supervised sounding, charting, and dredging of the sea around Peter I Island; on 2 February a party made the first landing on the island and established a provision depot for a future expedition. During February of 1931 Larsen attempted to make another landing on the island, but pack ice prevented the Norvegia from approaching closer than $36 \mathrm{mi}$. A month earlier the English Discovery II also had been turned back by pack ice $20 \mathrm{mi}$ from the island.

The United States ships Bear and North Star circumnavigated Peter I Island at a distance of $4 \mathrm{mi}$ in February 1941. During mid-February 1948, the Norwegian Brategg expedition, with Nils Larsen again the captain, landed the second party on the island; for 3 days they collected bird specimens and carried out geological investigations which "were the most interesting [investigations] and could have afforded much new information, if we would have been able to complete them" (Holderson, 1948). This party was evacuated 13 February because of encroaching pack ice. Two days later, the U.S.S. Burton Island and U.S.S. Edisto arrived and put a small party ashore for an hour (Commander Task Force 39, Annex IA, p. 18). The Chilean Naval vessel Baquedano landed a party in January 1956, at Sandefjord Bay (Thomas, 1957); no reports of their observations have been found. Helicopters launched from the USCGC Eastwind photographed the island in January 1957, but no landing was attempted (Henry Dater, personal communication, 1964).
The U.S.S. Burton Island, an icebreaker, landed parties both by boat and helicopter on the afternoon of 29 February 1960. Craddock was a member of a party which landed by boat on the shore of Norvegia Bay north of Cape Ingrid (Figure 2); approximately $2.5 \mathrm{hr}$ were available for geologic observation and collection. Echo-sounder profiles were obtained by the ship, and the shoreline was mapped by radar. The data and specimens collected on this visit form the basis for the present report.

The Russian ship $O b$ carried out oceanographic studies near the island during the next month (Dubinin, 1960). In January 1964, the U.S. oceanographic ship Eltanin made an approach to Peter I Island (Antarctic Report, 1964). During the 1970-1971 austral summer, an Argentine expedition conducted biological studies at the island.

Landings have been made at three locations on Peter I Island. Two of the locations are at Sandefjord and Norvegia bays, which are separated by the rock promontory of Cape Ingrid (Figures 2,3) and which have the largest areas of exposed rock accessible from the sea. The two landings by Nils Larsen, the 1948 landing from the Burton Island, and the 1956 Chilean landing all took place in Sandefjord Bay. There are only brief descriptions of geologic observations made during these landings. Holtedahl (1929, p. 83-88) mentions "richly olivine-bearing, very fine-grained rock" collected from the southeast corner of Sandefjord Bay. In 1960 the party from the Burton Island landed in Norvegia Bay, and Craddock was able to work briefly along the entire 50-ft-wide beach from Cape Ingrid northward to Nils Larsen Glacier. The third location is near the northeast corner of the island, where a helicopter from the Burton Island landed in 1960. A two-man party was left there for several hours, but it was unable to reach rock because of crevasses.

\section{GEOMORPHOLOGY}

Peter I Island is a glacier-capped volcanic island approximately $6 \mathrm{mi}$ wide and $13 \mathrm{mi}$ long (Figure 4 ). The highest point, according to the 1960 survey, is about $5750 \mathrm{ft}$ above sea level (U.S. Navy Hydrographic Office Chart 6713). The east and west sides of the island are marked by precipitous cliffs interrupted by several glaciers which project into the sea. The principal rock outcrops occur along these cliffs and along the gentler sloping north end of the island. The southern third of the island is a gently inclined ice surface with isolated small rock outcrops; the ice at the seaward termination of this slope is probably grounded. Exposed rock is estimated to form less than $5 \%$ of the island's surface.

The summit of the island is completely covered by snow and ice, but a circular depression roughly $300 \mathrm{ft}$ in diameter, surrounded by an indistinctly defined rim ris- 


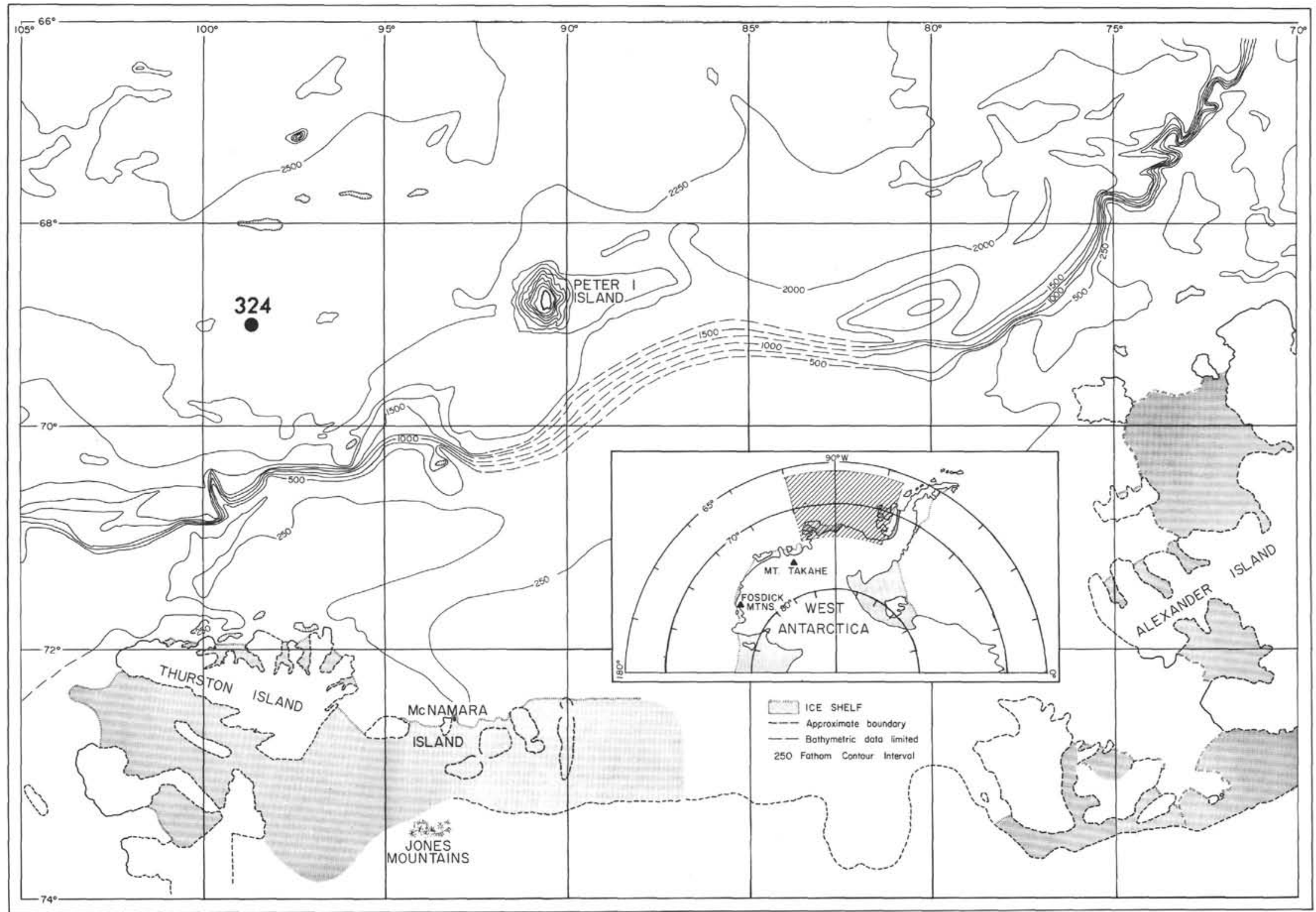

Figure 1. Bathymetric map of the Bellingshausen Sea (after U. S. Navy Hydrographic Office Chart 6638). 


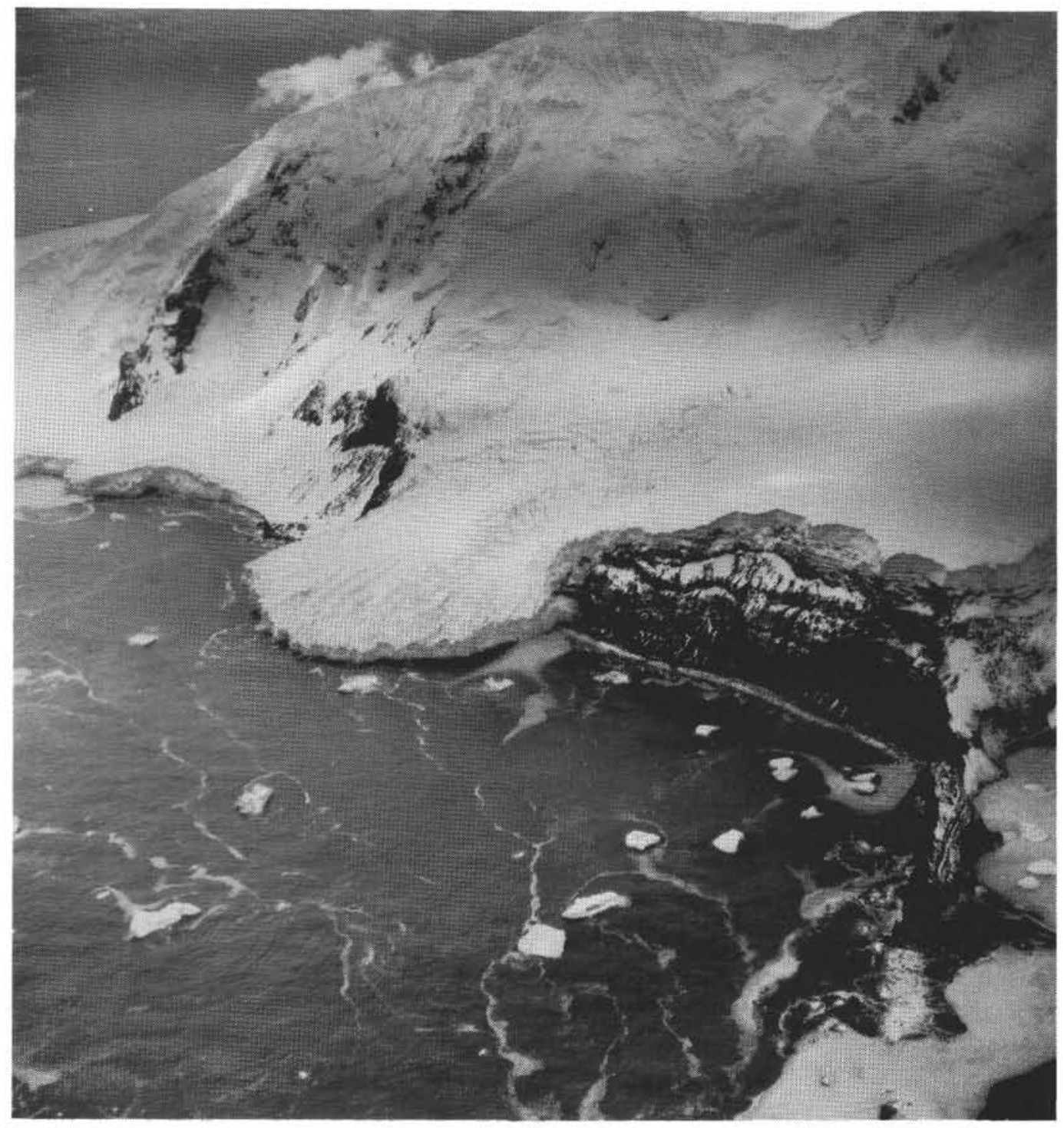

Figure 2. Aerial view of west side of Peter I Island showing Nils Larsen Glacier (left), Norvegia Bay, and Cape Ingrid (right). U. S. Navy photo, 29 February 1960.

ing about $100 \mathrm{ft}$ above the depression, suggests the presence of a volcanic crater beneath a relatively thin ice cap. No signs of recent volcanic activity were observed, and the seeming lack of tephra layers in the numerous ice cliffs suggests a considerable period of inactivity; none of the previous expeditions reported any volcanic activity. A single $\mathrm{K}-\mathrm{Ar}$ whole-rock age of 12.5 \pm 1.5 m.y. (Table 1) was obtained on specimen PI-5, olivine basalt collected from a flow at Cape Ingrid; this apparent age also suggests the possibility of long inactivity. On the other hand, the elevation of $5750 \mathrm{ft}$ above sea level obtained for the highest peak in 1960 is much greater than the readings of about $4000 \mathrm{ft}$ obtained by von Bellingshausen in 1821 .

There are at least four large valley glaciers which terminate as ice tongues floating in the sea (Figures 2, 5). The fan-like terminus of the largest glacier is about $3 \mathrm{mi}$ wide. Ice cliffs of approximately $80-100 \mathrm{ft}$ in height occur at the foot of these glaciers and along the edges of the plateau-like ice sheets which border much of the island. Crevasses are abundant in the valley glaciers, but they are important only locally in the plateau areas. Numerous new icebergs (Figure 3) and several avalanches observed during the 2-day visit by the Burton Island in 1960 suggest fairly rapid ice movement. The snow accumulation rate in the Eights Coast area to the south is quite high (Shimizu, 1964), and Peter I Island, surrounded by or close to open water for a short period each austral summer, may have a similarly high or even higher accumulation rate.

Holtedahl (1929) discusses the geomorphic features of the island, based on photographs taken by the Norvegia expedition. It is his opinion that the precipitous east side of the island was formed by intensive wave erosion, instigated by a postulated prevailing easterly wind, and that the west side was eroded by both waves and glacial action. $\mathrm{He}$ also infers extensive marine planation, both at present and during an earlier high 


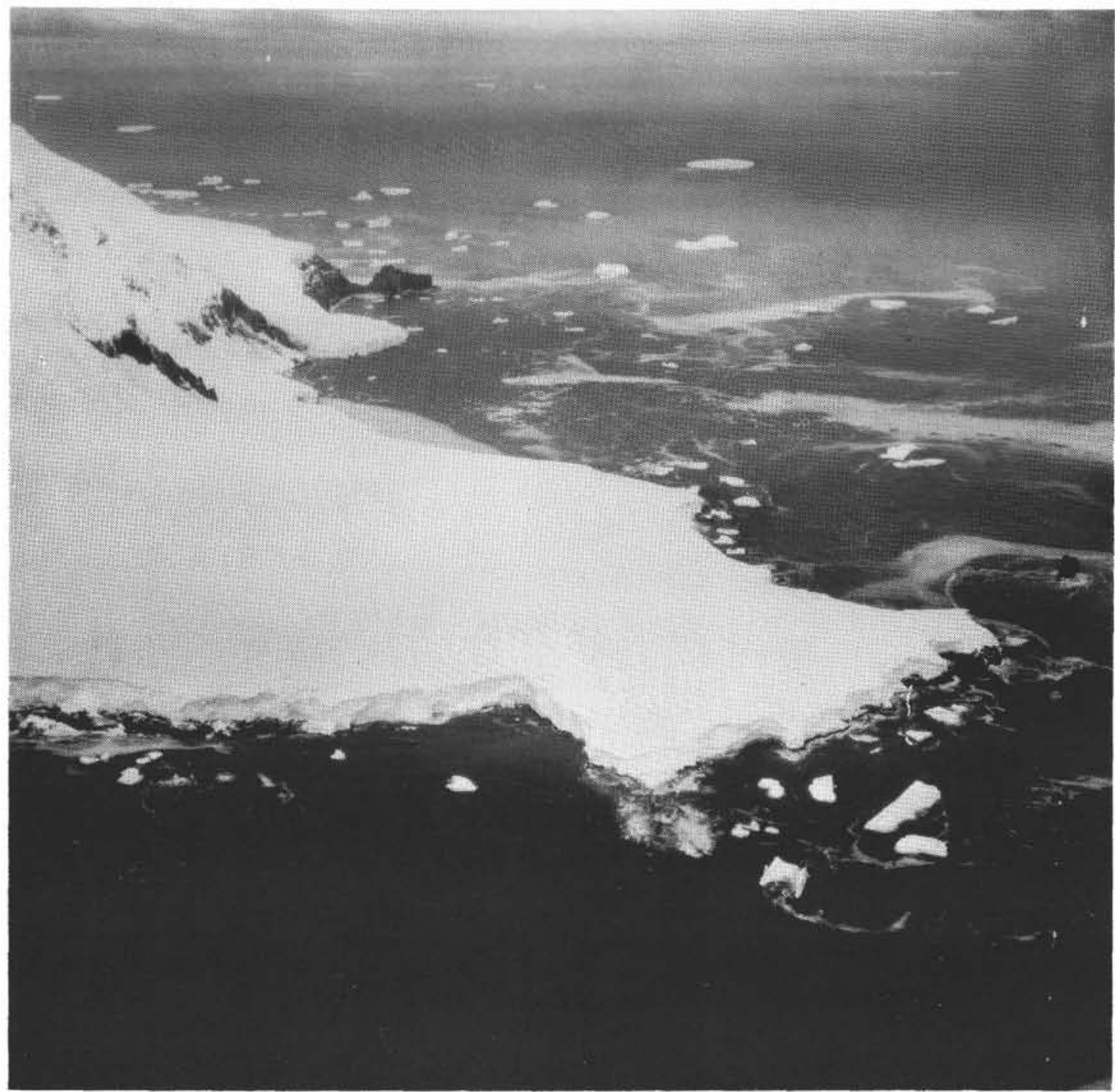

Figure 3. Aerial view to south along west side of Peter I Island showing Cape Eva (foreground), Nils Larsen Glacier, and Cape Ingrid (distance). U. S. Navy photo, 29 February 1960.

stand of sea level. Definition of the underwater morphology of the island during the 1960 survey confirms the existence of a well-developed marine platform.

The base of Peter I Island lies approximately 2000 fathoms below sea level and is roughly circular in form, with a diameter greater than $40 \mathrm{mi}$ (Figure 4). The 2000 -fathom base level extends about 45 n.mi. southeastward to the base of the continental slope. The submarine slope around the island averages about $10^{\circ}$ to $15^{\circ}$, except for the distinct subhorizontal platform 15$20 \mathrm{mi}$ in diameter and less than 200 fathoms deep which surrounds the island. The width of this platform east and west of the island is somewhat greater than north and south, as expected from Holtedahl's concept of areas of maximum erosion. It seems probable that the platform cutting has taken place with sea level nearly the same as, or possibly lower than, at present. A comparison of an east-west profile of the island, using the sea floor as a base, with other volcanic islands and guyots of the Pacific (Figure 6) shows their similarities and indicates that with continued erosion and subsidence Peter I Island would become a typical guyot. Projection of the $15^{\circ}$ submarine slope to form a volcanic cone would place the restored summit at approximately $7000 \mathrm{ft}$ above sea level (Figure 4). However, the low apparent dips of the exposed volcanic strata suggest that the volcano may have been more shield-like and that the summit may never have been much higher than at present. The possibility exists that an increase in the amount of more viscous trachyandesitic magma during the later stages of activity may have resulted in steeper original slopes on the upper part of the island.

Cape Ingrid represents a unique land form on the island. It is a rocky promontory which extends out perpendicularly from the west coast (Figures 2, 3). Its present form can be partially attributed to differential erosion of volcanic strata which have been intruded by a small resistant pluton. The cape forms the southern boundary of Norvegia Bay and, along with Nils Larsen Glacier, protects the narrow beach of this bay. The 

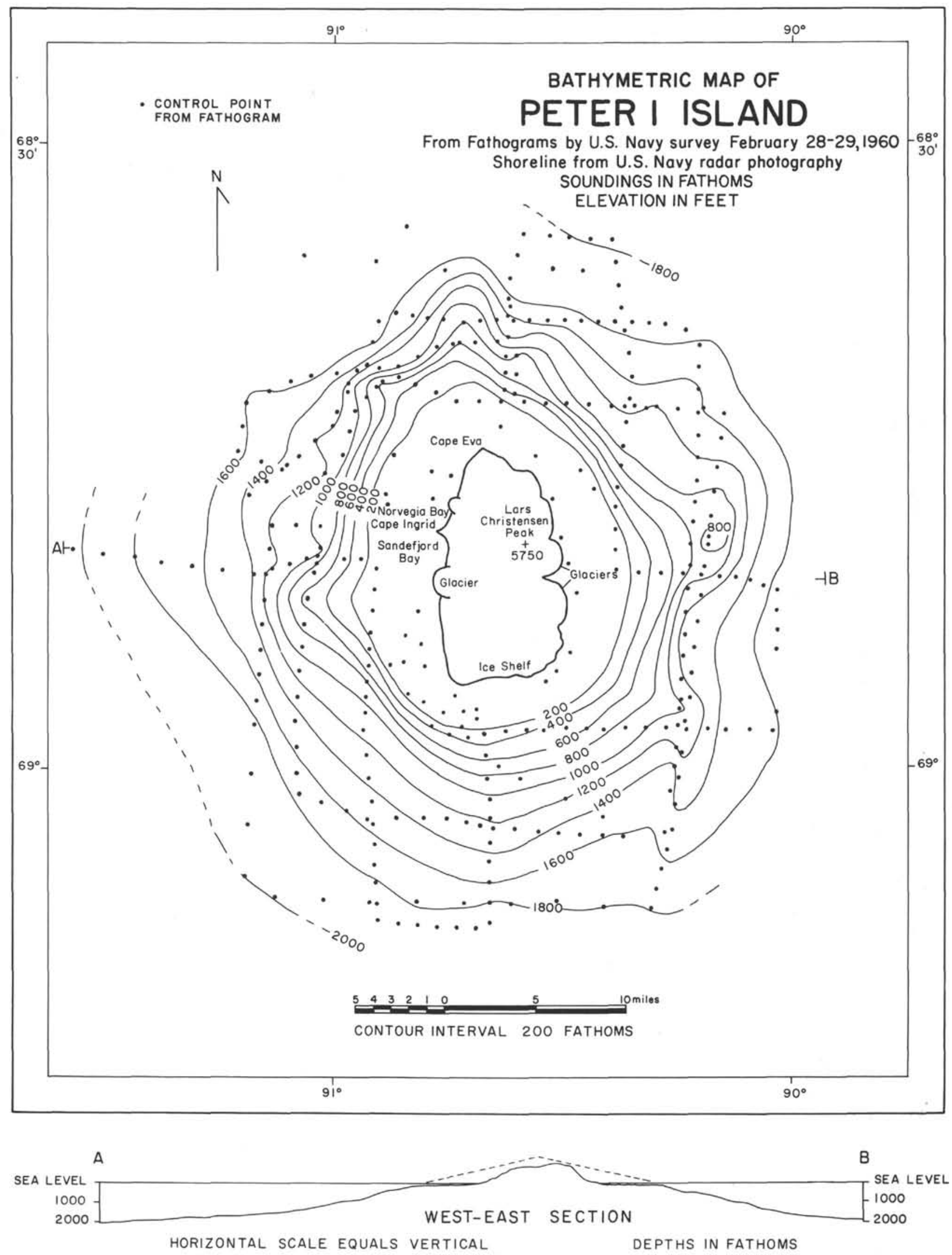

Figure 4. Bathymetric map of Peter I Island area, based on U. S. Navy survey, 28-29 February 1960. 
TABLE 1

Whole-Rock Analysis, Specimen PI-5

\begin{tabular}{lcccc}
\hline Specimen & $\begin{array}{c}\text { Material } \\
\text { Analyzed }^{\mathrm{a}}\end{array}$ & $\% \mathrm{~K}$ & $\mathrm{Ar}_{40} \mathrm{~b}^{\mathrm{b}} / \mathrm{K}_{40}$ & Age $\left(10^{6} \mathrm{yr}\right)$ \\
\hline PI-5 & $\begin{array}{l}\text { Olivine basalt, } \\
\text { whole-rock }\end{array}$ & 1.035 & 0.00073 & $12.5 \pm 1.5$ \\
\hline
\end{tabular}

${ }^{a}$ Analy sis by Geochron Laboratories, Inc., Cambridge, Massachusetts. Decay constants: $\lambda \mathrm{e}=0.585 \times 10^{-10} / \mathrm{yr}, \lambda \mathrm{b}=4.72 \times 10^{-10} / \mathrm{yr}$.

${ }^{\mathrm{b}}$ Radiogenic $\mathrm{Ar}_{40}$.

beach is composed of sand- to boulder-sized clasts of glacial ice and of the volcanic rocks which make up the adjacent cliffs (Figure 7). A $10-\mathrm{ft}$ conglomerate bed of well-rounded cobbles and boulders of ice and rocks occurs at the north end of the beach (Figure 8). Some of this material may be derived from the pack ice which surrounds the island most of the year. Above the narrow beach rise steep rock cliffs, capped in turn by an active ice cliff (Figure 2).

\section{STRUCTURE}

Peter I Island is a volcanic mountain composed of interbedded flows of basalt and more siliceous lavas, which range in thickness from 2 to at least $40 \mathrm{ft}$ with irregular lateral variations. The proportions of dark basalts and more siliceous rocks seem quite variable; outcrops along the north coast appear from the air to be mainly basalt while at Cape Ingrid light-colored rocks are an important part of the sequence. The greatest observed dip of these volcanic rocks is about $5^{\circ}$ seaward at Cape Ingrid. Strata on either side of the cape show gentle dips away from the cape, suggesting that there may have been an original headland resulting from a subsidiary eruptive center or a series of overlapping lava tongues from the main vent. The existence of the cape may be largely due to this headland; the presently exposed intrusive plug may have acted as a buttress only during the last stages of erosion.

The dark gray basaltic lavas vary from dense to highly vesicular; most vesicles are small and nearly spherical, but some are distinctly elongate. A few sur-

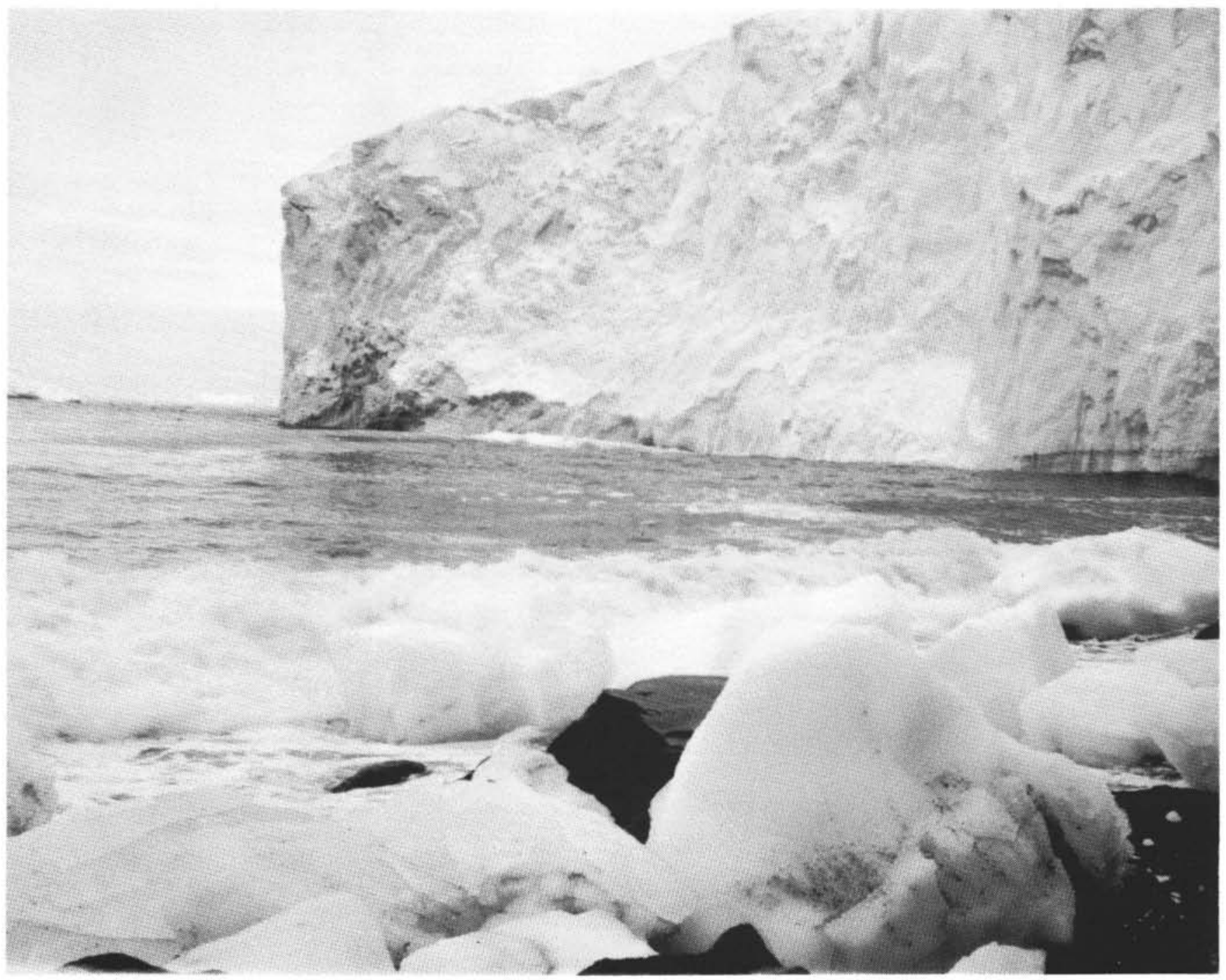

Figure 5. Terminus of Nils Larsen Glacier, from the beach in Norvegia Bay, 29 February 1960. Height of ice cliff is estimated at 80 feet near the beach. C. Craddock photo. 


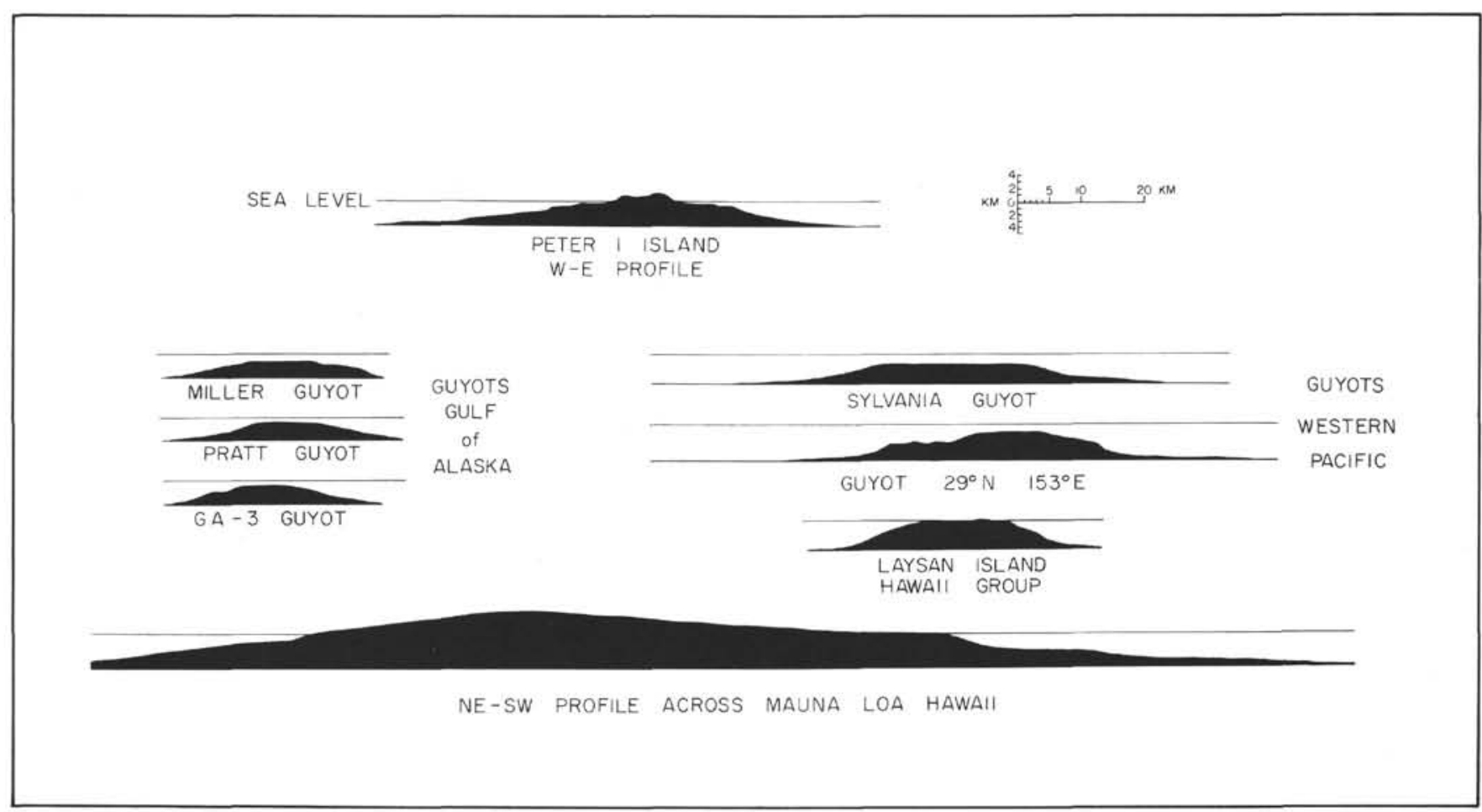

Figure 6. Profiles of some Pacific volcanic islands and guyots.

faces have pahoehoe structure and ropy crusts (Figure 9); no pillow structures were seen in any of the volcanic rocks. Columnar jointing is common in the thicker basalt flows. Some basalt flows contain megascopic olivine as crystals and granular inclusions. Some distinct gray flows are separated by highly vesicular basalt which is oxidized to a reddish-brown. At the base of the talus slope separating the rock cliff from the beach, just north of Cape Ingrid, a 6-in., rounded, highly vesicular basalt specimen was collected; this rock probably formed as a bulbous squeeze-up (Macdonald, 1967).

At Norvegia Bay light-colored trachyandesite flows are common and occur interbedded with the more abundant basalts. These rocks contain numerous and conspicuous gabbroid inclusions. Flow banding and deformed vesicles are present in some flow units.

In addition to the basalt and trachyandesite flows, the Norvegia Bay sequence also contains several breccia beds of reworked older volcanic material. The largest clast observed is about $8 \mathrm{ft}$ long. These beds are heterogeneous in both composition and texture; some are massive, but some are stratified. One 8 -ft bed contains a large angular block of trachyandesite with gabbroid inclusions.

The stratified rocks have been intruded by both dikes and small stocks. Many small basalt dikes cut the strata along Norvegia Bay; they are commonly less than 18 in. wide. Plug-like masses of basalt (?) were seen near Cape Eva, and other light gray intrusives occur at Cape Ingrid and at the southeast corner of Sandefjord Bay. These intrusive bodies are not abundant and appear to represent only a minor fraction of the island's total rock volume.

The gentle dips of the layers comprising Peter I Island suggest that its form at maximum development was probably shield-like, resembling the Hawaiian vol- canoes but with slightly greater slopes. Its submarine profile, as described in the previous section, has slopes which average $10^{\circ}$ to $15^{\circ}$, but vary from $5^{\circ}$ to $20^{\circ}$; these compare with $4^{\circ}$ to $6^{\circ}$ for Hawaiian volcanoes (Rittman, 1962, p. 119, and our Figure 6).

\section{DREDGED ROCKS DESCRIBED BY BROCH}

Broch (1927) has presented the only previous report on rock specimens from Peter I Island. The 175 rocks that he examined were dredged in 1927 from depths of 6 to 7 fathoms off the west coast of the island near Cape Ingrid. He described the collection as poorly rounded beach pebbles ranging between hazelnut- and twice fistsize, and he identified three rock types: basalt, andesite, and trachyandesite.

Basalt specimens described by Broch are dense to highly vesicular with hypocrystalline to holocrystalline porphyritic textures. Olivine is the principal phenocryst, occurring as euhedral individuals up to $2 \mathrm{~mm}$ long with some spinel inclusions; iddingsite rims are common. Euhedral plagioclase crystals as large as $3 \times$ $0.5 \mathrm{~mm}$ are the next most common phenocrysts; individuals with oscillatory zoning range from $\mathrm{An}_{70}$ to $\mathrm{An}_{60}$ with prominent albite and pericline twinning. Augite phenocrysts occur in some of the basalt specimens; they are euhedral but corroded crystals up to $5 \mathrm{~mm}$ long, gray-brown with a tinge of violet, lamellar twinned, and zoned with common hourglass structure. Glassy specimens contain only olivine as phenocrysts. The matrix of the basalt is composed mainly of progressively zoned plagioclase with a maximum Anso content, and augite which optically resembles the phenocrysts. Olivine and metallic minerals in roughly equal amounts are subsidiary components, and apatite is a minor constituent. The matrix 


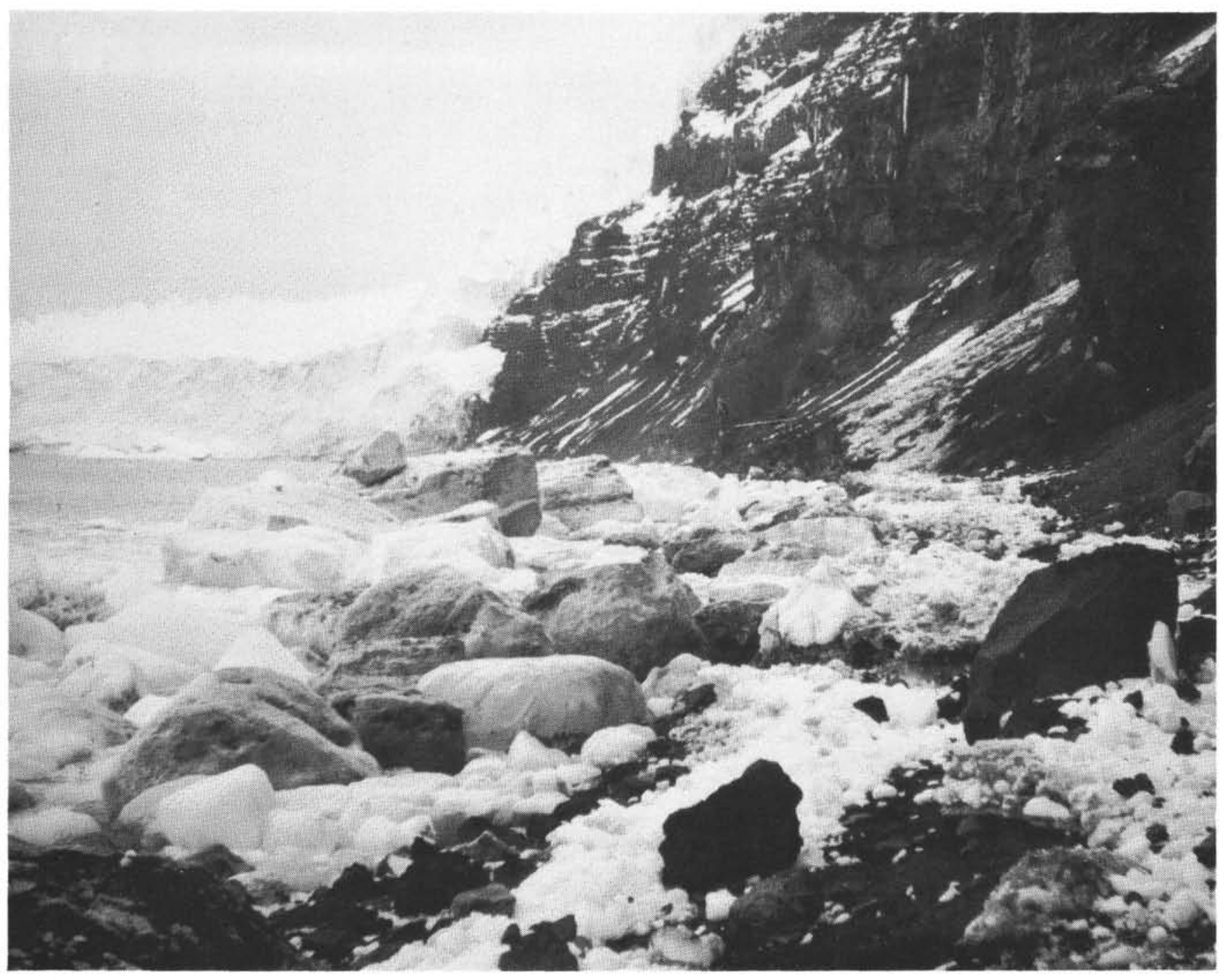

Figure 7. Clasts of glacial ice and volcanic rocks on the beach, Norvegia Bay, 29 February 1960. C. Craddock photo.

crystals average about 0.05 to $0.1 \mathrm{~mm}$ in length. A dark red translucent matrix occurs in some fragments and may be partly devitrified hyalopilitic rock. Calcite occurs in minor amounts as vesicle fillings.

Broch's 11 andesite specimens are aphanitic and dense to partially vesicular with plagioclase phenocrysts as long as $1 \mathrm{~mm}$ and lesser phenocrysts of olivine, basaltic hornblende, green diopsidic augite, and brown basaltic augite. The plagioclase occurs as corroded idiomorphs zoned from $\mathrm{An}_{35}$ to $\mathrm{An}_{20}$ and as unzoned $\mathrm{An}_{32}$ crystals. Olivine of similar size is idiomorphic to corroded, and basaltic hornblende clouded with metallics occurs as somewhat rounded rectangular grains. Diopsidic augite phenocrysts are slightly smaller, but similarly corroded; lamellar twinning is common. One individual crystal of basaltic augite was seen. The matrix is very fine grained and is predominantly albitetwinned plagioclase. Brown augite with distinct hourglass structure is the next most common mineral, occurring as small $(0.01 \times 0.03 \mathrm{~mm})$ prisms. Small metallic grains are common, and minor apatite and rare zircon are also present.
The 11 trachyandesite specimens are light gray to pink holocrystalline porphyries with pilotaxitic to trachytic matrices and many irregularly bounded pores. Phenocrysts include (1) plagioclase, which is progressively zoned from $\mathrm{An}_{40}$ to $\mathrm{An}_{10}$, (2) basaltic hornblende which is strongly pleochroic and commonly decomposed to metallics and diopsidic augite, (3) biotite similar in appearance and alteration to the basaltic hornblende, (4) diopsidic augite which may be the decomposition product of hornblende, and (5) apatite containing needle-like inclusions oriented parallel to the c axis which impart a pseudopleochroism to the blue-gray crystals. Plagioclase is the main matrix mineral; it is progressively zoned from $A n_{75}$ to $\mathrm{An}_{10}$ with some albite and Carlsbad twinning. Anorthoclase may be present as rims and individual crystals. Diopsidic augite, pale green to brown with irregular boundaries, is common. Irregular metallics are also common, and sphene and zircon occur as rare idiomorphs. Apatite is present as small inclusions in plagioclase. A very small amount of a colorless, low-index material occurs in interstices and may be glass. 


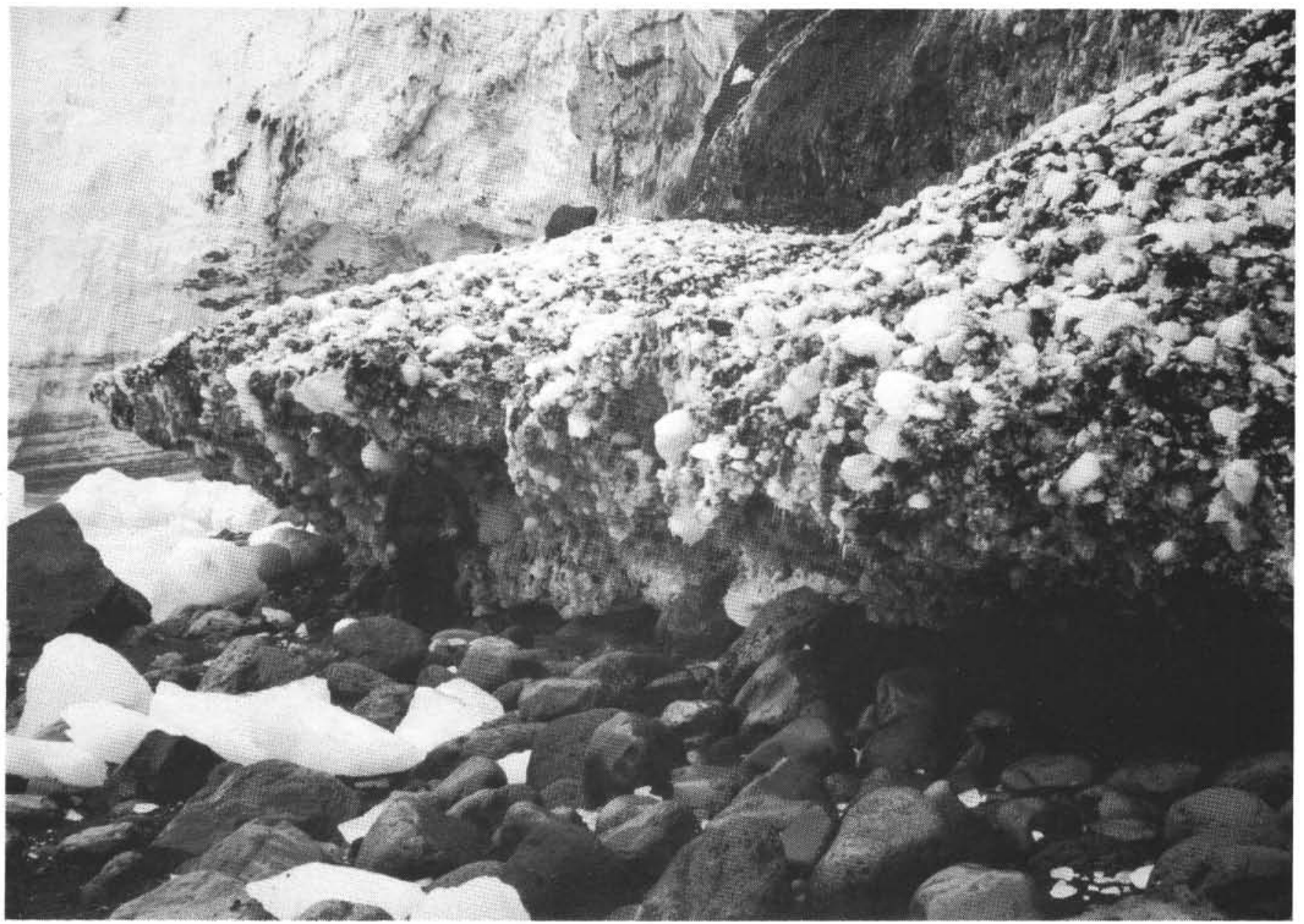

Figure 8. Conglomerate bed with ice matrix and clasts of glacial ice and volcanic rock, north end of beach, Norvegia Bay, 29 February 1960. E. Doss photo.

\section{ROCKS COLLECTED IN 1960 ON THE SHORE OF NORVEGIA BAY}

The rock collection obtained by Craddock on Peter I Island contains 29 specimens from the shore of Norvegia Bay between Cape Ingrid and Nils Larsen Glacier. Sixteen specimens were collected in place, and the remainder are beach cobbles and talus clasts. Thirteen specimens are basalt, mainly from lava flows but including one specimen from a dike; one specimen has an inclusion of trachyandesite, another an inclusion of granular olivine. The remaining 16 specimens are probably all trachyandesite, and 12 contain inclusions of coarse-grained gabbroid rocks.

\section{Basalts}

The basaltic specimens are dense to scoriaceous and dark gray to reddish-brown, the latter oxidized and generally more vesicular. Microscopic textures range from hypocrystalline to holocrystalline, and from nonporphyritic to porphyritic with the matrices intersertal to intergranular felty to trachytic. Olivine is the most common phenocryst, followed by minor plagioclase and clinopyroxene; excluding the pyroxene, these minerals have a seriate relationship with the matrix. Few phenocrysts exceed $1.5 \mathrm{~mm}$ in length; they more commonly range from 0.5 to $1.0 \mathrm{~mm}$. Matrix crystals of all minerals average less than $0.3 \mathrm{~mm}$, with plagioclase forming the largest crystals. Porphyritic textures are pronounced only in specimens with intersertal matrices. The mineralogical proportions of the basalt specimens show moderate variations, as summarized in Table 2.

Olivine occurs as euhedral crystals that optically have no apparent zoning. Their maximum length is 1.5 $\mathrm{mm}$, but they range down to matrix size; the largest crystals are embayed as a result of partial remelting or chemical reaction with the magma. Small euhedral inclusions of a spinel-type mineral occur as rare, randomly oriented components in the olivine crystals. Alteration of olivine to an iddingsite-type mineral is common only in specimens PI-1, 9, and 15; the first of these is a dense basalt, the others are oxidized scoriaceous specimens.

Specimen PI-1 contains a cluster of olivine grains with allotriomorphic granular texture, uneven extinction which may be related to translation laminae (Wilshire and Binns, 1961), and reaction rims of finer granular olivine and clinopyroxene. Metallic grains form a zone of inclusions along the border of the cluster. These characteristics are similar to those found 


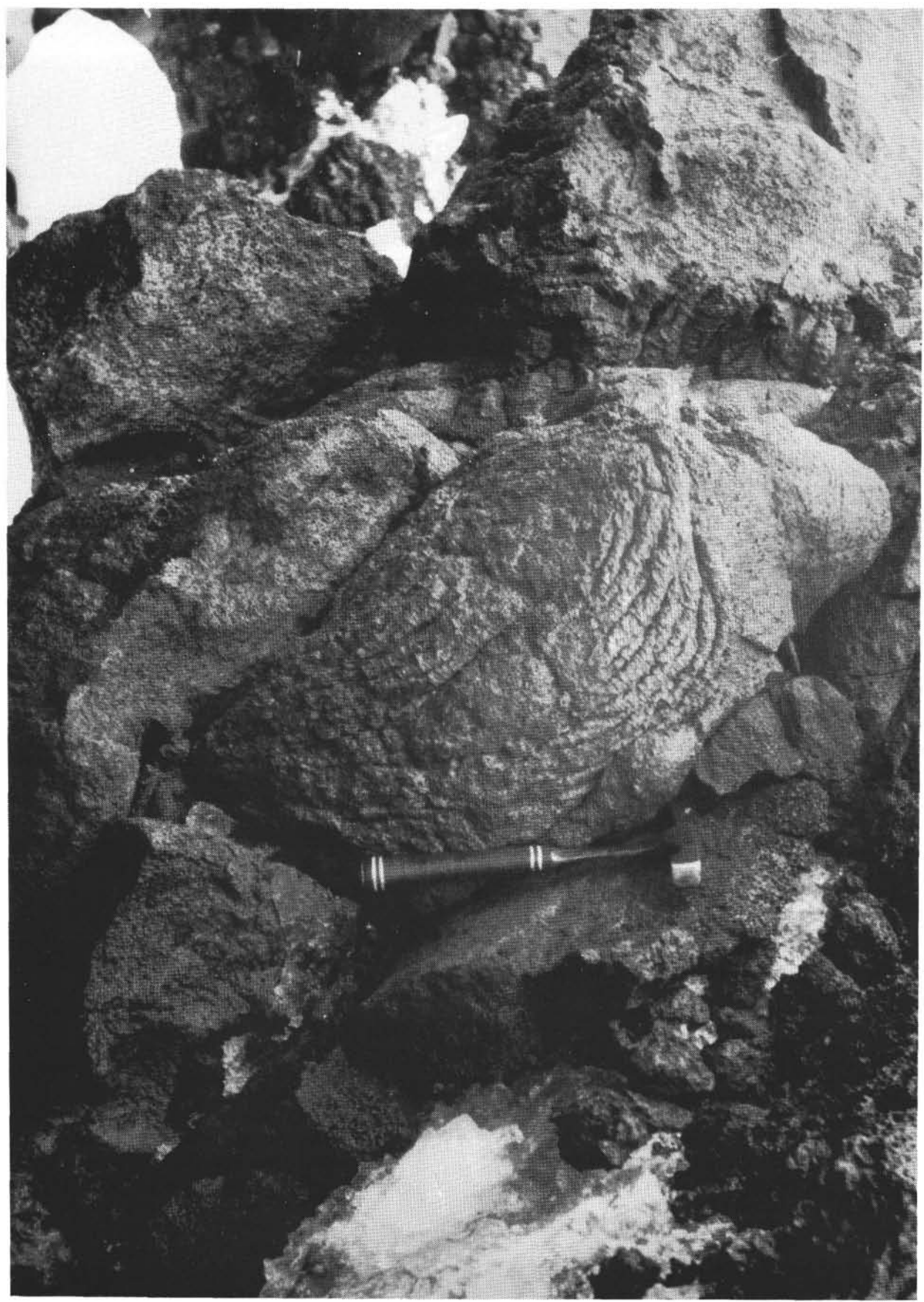

Figure 9. Ropy pahoehoe basalt flow, Norvegia Bay. C. Craddock photo. 
TABLE 2

Modal Analyses of Peter I Island Basalts

\begin{tabular}{lrrrr}
\hline \multirow{2}{*}{$\begin{array}{c}\text { Minerals } \\
\text { (volume \%) }\end{array}$} & PI-1 & \multicolumn{1}{c}{ Specimen No. } \\
\hline Olivine & 17.2 & 11.4 & 9.8 & \multicolumn{1}{c}{7} \\
\hline $\begin{array}{l}\text { Plagioclase } \\
\text { Pyroxene }\end{array}$ & 38.2 & 34.6 & 25.3 & 30.6 \\
$\quad$ matrix & 30.0 & 34.4 & 41.6 & 38.4 \\
$\quad \begin{array}{l}\text { phenocrysts } \\
\text { Metallics }\end{array}$ & 0.2 & - & - & 3.2 \\
& 14.4 & 19.6 & 23.4 & 18.0 \\
\hline
\end{tabular}

in peridotite nodules in basalts and probably indicate a deep-seated origin for this inclusion.

Plagioclase occurs principally as a groundmass mineral and only rarely as phenocrysts with oscillatory zoning. Corroded remnants of large plagioclase crystals are more common than phenocrysts; they may be xenocrysts, perhaps related to the coarse-grained inclusions prevalent in the trachyandesites. Matrix plagioclase crystals are generally euhedral to subhedral laths twinned according to the albite and Carlsbad laws. Their average size is about $0.2 \times 0.05 \mathrm{~mm}$, except for specimen PI-9 which contains crystals to $0.7 \times 0.3$ $\mathrm{mm}$ with an average size of about $0.5 \times 0.1 \mathrm{~mm}$.

Table 3 lists anorthite contents of individual crystals as determined microscopically by Carlsbad-albite extinction angles and Tobi's (1963) high-temperature plagioclase curves. Possible errors in turning angles and in chart interpolation amount to $\pm 3 \% \mathrm{An}$. Values in this table represent maximum measured An contents of zoned crystals and early matrix crystals with twinning developed well enough for measurement. Anorthite contents determined with electron microprobe analysis of calcium by Bastien are also given in Table 3. The microprobe analyses represent spot determinations with a $2 \mu \mathrm{m}$ diameter electron beam. There is $\pm 2 \%$ An uncertainty related to the microprobe determinations of calcium in the synthetic standards compared with their chemical analyses. It should be emphasized that the accuracy of the compositional values stated here relates to comparisons within the Peter I Island suite and not necessarily to absolute feldspar compositions. Comparison of extinction angle and microprobe methods reveals generally close agreement in specimen PI-7, but a greater spread of results in PI-8. This reflects mainly the greater range in size of crystals analyzed with the microprobe in PI-8. The variation in feldspar composition between the two specimens appears to be related to differences in cooling histories. The greater size of feldspar crystals in PI-7 suggests a slower cooling rate, with feldspar crystallization proceeding further before matrix clinopyroxene precipitation was initiated. Feldspars in PI- 8 were in greater competition for calcium with the clinopyroxene during crystallization than those of PI-7.

Clinopyroxene and plagioclase are the principal rock-forming minerals in the Peter I Island basalts; they occur in roughly equal amounts and comprise more than $60 \%$ of the volume of the rock. Most of the clinopyroxene is in the matrix, with only one specimen (PI-7) containing as much as $3 \%$ phenocrysts. The
TABLE 3

Anorthite Content of Plagioclase in Six Peter I Island Basalts

\begin{tabular}{cccccc}
\hline \multicolumn{5}{c}{ Specimen PI- } \\
3 & 4 & 7 & 8 & 9 & 15 \\
\hline \multicolumn{5}{c}{ Maximum An \% of Individual } \\
\hline \multicolumn{5}{c}{ Crystals (by Microscope) } \\
\hline 50 & 51 & 47 & 51 & 55 & 53 \\
50 & 52 & 53 & 51 & 55 & 54 \\
52 & 53 & 54 & 52 & 55 & \\
& & & 53 & 56 & \\
& & & 58 \\
\hline
\end{tabular}

Electron Microprobe Analysis for $\mathrm{Ca}$ (range of An \% within individual crystals)

\begin{tabular}{cc}
$51-55$ & $39-51$ \\
$54-57$ & $41-42$ \\
$49-56$ & 42 \\
$51-53$ & $42-45$ \\
54 & 56 \\
& $57-61$ \\
\hline
\end{tabular}

clinopyroxene phenocrysts are corroded euhedra which reach a maximum length of $1.6 \mathrm{~mm}$. Twinning and progressive zoning are both common. The crystals are colorless to pale yellow-green, with pale brown outer zones similar in color to the matrix pyroxene. Matrix crystals are euhedral to anhedral and generally less than $0.1 \mathrm{~mm}$ in length. Optical determinations are very difficult, but both the phenocrysts and matrix crystals are probably in the diopside-augite group, with the phenocrysts possibly more diopsidic.

Opaque metallic minerals form an important component of the matrix; modal abundances range from 14.4 to 23.4 volume \%. They are most commonly euhedral equant crystals less than $0.02 \mathrm{~mm}$ in diameter; subhedral and anhedral crystals are not unusual, but skeletal forms are rare. The more poorly crystallized rocks such as PI-3, 5, and 7 contain larger amounts of these opaque minerals, which may reflect a more rapid cooling that inhibited olivine and pyroxene from reacting with the residual liquid, thereby leaving excess iron and titanium to form magnetite and ilmenite. Low values for magnetite and ilmenite in the normative mineral calculations (Table 5) also suggest incomplete reaction.

Apatite occurs as a rare accessory mineral. It can only be found in specimens with a holocrystalline groundmass, as small rod-shaped crystals. Zircon is even more rare and is found as small idiomorphs. A probable zeolite mineral occurs as a rare vesicle coating.

\section{Trachyandesites}

The trachyandesites are dense porphyritic aphanites, pale pinkish-gray to light gray. Microscopic matrix textures are trachytic to pilotaxitic, with $5 \%$ to $10 \%$ irregularly shaped pores. Plagioclase and basaltic hornblende form the phenocrysts, which are as long as $2.6 \mathrm{~mm}$. The plagioclase is distinctly zoned, and twinning according to the albite, Carlsbad, and pericline laws is poor to well developed. Anhedral resorbed 
TABLE 4

Modal Mineral Estimates of Coarse-Grained Inclusions

\begin{tabular}{l|c|c|c|c|c|c|c|c|c|c}
\hline \multirow{2}{*}{\multicolumn{1}{c|}{ Mineral }} & \multicolumn{10}{c}{ Specimen PI- } \\
\cline { 2 - 10 } & 16 & 18 & 19 & 20 & 21 & 22 & 24 & 25 & 26 & $29 \mathrm{a}$ \\
\hline Plagioclase & $\sim 50$ & 50 & 30 & $\sim 50$ & $\sim 50$ & $\sim 40$ & $\sim 50$ & 50 & 75 & $30-40$ \\
$\mathrm{An}^{\mathrm{a}}$ & 48 & $?$ & 45,46 & 51,52, & 45,46 & 69,70, & 44,44 & $?$ & $31-42^{\mathrm{b}}$ & 50 \\
& & & & 56 & & 72 & & & & \\
Diopsidic augite & - & $<10$ & $10-20$ & 15 & $<2$ & 40 & $15-20$ & $15-20$ & - & $30-40$ \\
Basaltic hornblende & $5-10$ & $25^{\mathrm{c}}$ & 15 & $<5$ & $\sim 30$ & - & $5-10$ & 20 & $20^{\mathrm{d}}$ & - \\
Low-iron amphibole & $30-40$ & $15-20$ & $10-15$ & 25 & $10-15$ & 5 & $5-10$ & $25-35$ & $<5$ & $<10$ \\
Olivine & - & - & 15 & $<5$ & $<<5$ & - & $<<5$ & - & - & - \\
Magnetite-ilmenite & $10-15$ & $25^{\mathrm{c}}$ & 10 & $<5$ & $10-15$ & $<2$ & $15-20$ & $25-30$ & $15^{\mathrm{d}}$ & 20 \\
Apatite & $<5$ & $<5$ & $<5$ & $1-2$ & $<5$ & - & $<5$ & $<3$ & 5 & $<5$ \\
Biotite & - & - & $<5$ & - & - & $<2$ & - & - & - & $<5$ \\
\hline
\end{tabular}

\footnotetext{
a Albite-Carlsbad and Tobi's high-temperature curves.

${ }^{b}$ Electron microprobe analysis, zoned from $\mathrm{An}_{34-42}$ in one grain.

${ }^{c}$ Opacite (totals $25 \%$ ).

$\mathrm{d}_{\text {Includes opacite. }}$
}

crystals with euhedral overgrowths in the same crystallographic orientation are common. Outer rims of alkali feldspar are present on all the feldspar phenocrysts. Carlsbad-albite twin combinations are not well enough developed for extinction angle measurements for composition determination. Maximum An content from microprobe analysis of phenocrysts in specimen $\mathrm{PI}-14$ is $\mathrm{An}_{22}$ near the grain center for one crystal; three other crystals had maxima of $A_{15}$, 15, and 17. Outer zones are as low as Ans. Or-Ab-An ratios were not determined. One small matrix grain shows zoning from $A n_{18}$ to $\mathrm{An}_{2}$. Specimen PI-19 contains an embayed phenocryst zoned from $\mathrm{An}_{27}$ to $\mathrm{An}_{22}$ and a matrix grain zoned from $\mathrm{An}_{28}$ to $\mathrm{An}_{26}$. Small euhedral apatite inclusions in random orientations are common.

The basaltic hornblende phenocrysts are corroded idiomorphs which are almost entirely replaced by aggregates of metallic and clinopyroxene granules. The parts which are unreplaced show strong pleochroism from pale yellow to deep red. These phenocrysts and their replacement products comprise about $5 \%$ to $10 \%$ of the rock volume.

The matrix of the trachyandesites is composed of feldspar (which forms $50 \%$ to $80 \%$ of the rock volume), augite, apatite, magnetite, and cryptocrystalline material. Textures range from orthophyric to trachytic; the feldspar crystals average about 0.2 to $0.1 \mathrm{~mm}$ in length, and the ferromagnesian minerals approximately $0.05 \mathrm{~mm}$. The feldspar is strongly zoned, both progressively and cyclically, undulatory and patchy extinction is common, and twinning is poorly developed as simple Carlsbad types. Electron microprobe examination reveals compositions as calcic as oligoclase. The index of refraction of much of the feldspar is less than 1.54, indicating compositions less calcic than An ${ }_{10}$; the amount of alkali feldspar and whether it is anorthoclase or orthoclase could not be determined. The classification of rocks of this type depends greatly on the composition and relative abundance of the feldspars. These specimens are provisionally classified as trachyandesites, with alkali feldspar $>1 / 3<2 / 3$ the total feld- spar; this assignment is supported by the chemical analyses (Table 5).

The matrix clinopyroxene is augite occurring as small euhedral to anhedral, light gray crystals with maximum extinction angles of $43^{\circ}$; they form less than $5 \%$ of the total rock volume. A metallic mineral, probably magnetite, also occurs as euhedral to anhedral equant grains. Apatite is present as clear, rod-shaped euhedral crystals, occurring as inclusions in feldspar. Zircon is a rare accessory mineral. A clear, low-index, isotropic substance occurs interstitially and may be glass.

\section{Inclusions in the Trachyandesites}

Coarse-grained, hypidiomorphic, granular gabbroid inclusions occur in many of the trachyandesite specimens. The mineralogy of these inclusions is similar, but the relative abundance of the minerals varies considerably. The mineral constituents, in order of generally decreasing abundance, are: plagioclase, diopsidic augite, low-iron hornblende, basaltic hornblende, titaniferous magnetite, apatite, olivine, and biotite. In Table 4 the volume percentages of the minerals are indicated as well as the plagioclase compositions, which are listed according to increasing anorthite content if known. The data are semiquantitative because the volume percentages are visual estimates from coarse-grained (grain size as large as 6 $\mathrm{mm}$ ) rocks in a single thin section for each specimen.

The plagioclase of the inclusions is anhedral and in grains as large as $6 \mathrm{~mm}$. Carlsbad, albite, and pericline twinning are prevalent; zoning is principally progressive, and crystals in contact with trachyandesite have apparent alkali feldspar rims. Compositions vary considerably between specimens (Table 4 ), but the maximum An contents of the individual grains in any one specimen are similar. Microprobe examination of PI-26 revealed zoning from $\mathrm{An}_{42}$ near the center to $\mathrm{An}_{34}$ at the edge of one crystal.

Clinopyroxene, probably diopsidic augite, is present both as a primary mineral and as an alteration product of basaltic hornblende. Anhedral forms are most com- 
Apatite is a ubiquitous accessory and forms euhedral to subhedral crystals as long as $0.5 \mathrm{~mm}$ that are commonly included in the feldspar, pyroxene, and amphiboles. The apatite crystals contain many extremely fine rod-like inclusions which parallel the $\mathrm{c}$ axis and possibly cause the faint pleochroism from pale gray to pale blue. This form of apatite is not uncommon in alkalic rocks (Tyrell, 1945; Le Maitre, 1962).

Olivine was observed in only four of the coarsegrained inclusions, and in amounts less than $5 \%$ in three of them. The crystals are anhedral with an iddingsitetype alteration along fractures. In specimen PI-19 a large plagioclase crystal surrounds a number of small, optically oriented olivine remnants. Their composition is undetermined, but a straight isogyre observed from an optic axis interference figure indicates a high $2 \mathrm{~V}$ and therefore a high forsterite content.

Biotite is the least abundant mineral, occurring in only three specimens. It shows strong pleochroism from pale yellow to ruby red and occurs as small anhedral crystals.

\section{Summary}

The 1927 and 1960 rock collections from Peter I Island are petrographically similar; however, there are a few differences. Andesite, as described by Broch, does not appear to be present in the 1960 collection, which consists wholly of basalts and probable trachyandesites. Only one small fragment of a coarse-grained inclusion occurs in the Broch collection, but these gabbroid inclusions are prominent in the later collection. The dredging naturally produces a random sample, but the collecting on the shore was selective and biased toward the rocks bearing the gabbroid inclusions.

\section{PETROCHEMISTRY}

Chemical analyses and normative minerals for six specimens of volcanic rocks from Peter I Island are given in Table 5. Four of these analyses and norms are from Broch (1927), and two are new here and based on the 1960 collection. Specimens B-2, B-3, and B-4 represent Broch's basaltic rocks, and B-5 his trachyandesite; in our collection specimen PI-5 is similar to Broch's basalt and PI-14 to his trachyandesite. The available chemical analyses show a distinctly bimodal grouping. However, Broch did not have a specimen of his andesite analyzed, and no specimen in the 1960 collection appears to be comparable to his andesite.

On the basis of their modes, specimens B-2, B-3, B-4, and PI-5 can be termed olivine basalts, but a more definite classification is difficult. The presence of calcic clinopyroxene and the apparent lack of reaction between olivine and pyroxene suggest that these rocks are alkali basalts rather than tholeiitic basalts (Wilkinson, 1967). The chemical compositions of the four basalt specimens allow some refinement of their classification. The low alumina values indicate that these rocks are not the high-alumina basalts of Kuno (1968), but the distinction between alkalic and tholeiitic basalts cannot be made definitely. Compared to the averages of Engel et al. (1965), these specimens are closer to alkali basalt than to tholeiitic basalt. On the basis of a weight $\%$ of $\mathrm{TiO}_{2}$ in excess of 1.75 , these basalts can be classified as oceanic (Chayes, 1964).
Irvine and Baragar (1971) propose a chemical classification system for dividing volcanic rocks into groups and series. In their system the Peter I Island basalts fall in a border region between alkaline and subalkaline rocks, some criteria favoring the former and others the latter. If the basalts are considered subalkaline, they clearly belong to the tholeitic series rather than the calcalkali series. In this system the Peter I Island basalts seem closest to olivine tholeiite with potash enrichment, but they also bear a similarity to slightly potassic alkali olivine basalt. Specimens B-3 and B-4 are nearly identical and approach the closest to hawaiite in composition.

The chemistry of the Peter I Island volcanic rocks can be compared with that of similar rocks from Hawaii (Macdonald and Katsura, 1962, 1964), Gough Island (Le Maitre, 1962), and three volcanic districts in West Antarctica (Craddock et al., 1964; Anderson, 1960; Fenner, 1938) in an alkali-silica plot (Figure 10). The five chemical analyses of the four Peter I Island basalts plot near the transitional rocks of the Hawaiian suite, and the overlap in the latter between the alkalic and tholeiitic series is evident. This diagram suggests similarities between the well-documented Hawaiian and the poorly sampled Peter I suites. It also shows that the Peter I Island basalts are near the alkalic-tholeiitic boundary, but that the more siliceous rocks are probably in the alkaline series.

The solidification index (SI) of Kuno et al. (1957) for the analyses in Table 5 are given in Table 6 . Values in the range of 35 to 40 indicate probably limited fractionation of primary magma; lower values indicate greater fractionation. In Hawaii the tholeiites commonly have SI values between 30 and 40 while the alkalic rocks are 15 to 20 but with values as high as 40 (Kuno, 1962). Although the Peter I Island basalts have high SI values, the statistical evidence of Kuno does not establish a tholeiitic character.

On the basis of petrographic study, specimens B-5 and PI-14 have been termed trachyandesites. Because definitions of the intermediate rocks vary and because our knowledge of the mineralogy of these two specimens is incomplete, we have retained Broch's (1927) rock name in the interest of consistency. The AFM diagram of Kuno (1968) shows these two specimens to lie in the trachyandesite field.

As with the four basalt specimens, efforts to classify these two trachyandesite specimens by the Irvine and Baragar (1971) systems produce cloudy results. Alkalisilica and AFM plots indicate these rocks belong to the alkaline series, but other diagrams suggest transitional to subalkaline affinities. If these rocks are considered subalkaline, this system classifies B-5 as dacite and PI14 as rhyolite; but these names do not fit well with either the chemistry or known mineralogy and must be rejected. However, if the specimens are treated as alkaline rocks, the system classifies B-5 as a probable benmorite and PI-14 as a trachyte. Both rocks plot near the trachyte field on the alkali-silica plot of Macdonald and Katsura (1962) for the Hawaiian lavas.

The Peter I Island trachyandesites fall on the trachytic side of the Daly gap identified with oceanic basalt-trachyte associations, as defined by Chayes in Tilley and Muir (1964) in terms of silica, $\mathrm{CaO}$, total 


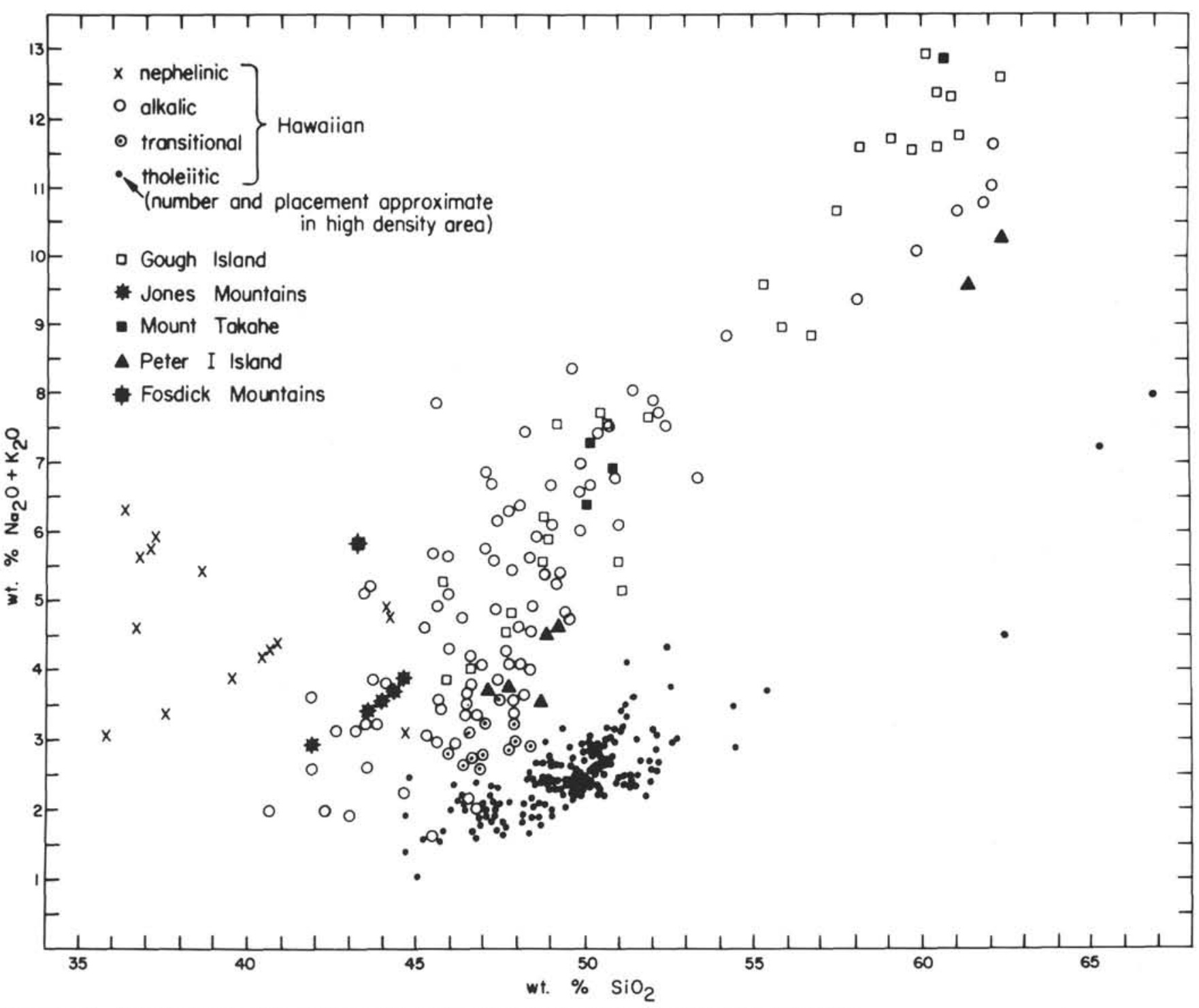

Figure 10. Alkalis versus silica diagram for volcanic rocks from selected districts (see text).

TABLE 6

Solidification Index (SI) of Six Rock Specimens from Peter I Island

\begin{tabular}{ccccccc}
\hline & B-2 & B-3 & B-4 & PI-5 & B-5 & PI-14 \\
\hline $\mathrm{SI}^{\mathrm{a}}$ & 40 & 34.6 & 34.4 & 33 & 8.8 & 6.9 \\
\hline${ }^{\mathrm{a}} \mathrm{SI}=$ & $\mathrm{MgO} \times 100 / \mathrm{MgO}+\mathrm{Fe}_{2} \mathrm{O}_{3}+\mathrm{Na}_{2} \mathrm{O}+\mathrm{K}_{2} \mathrm{O}$. \\
\hline
\end{tabular}

iron, and differentiation index. Chayes (1964) pointed out the bimodal character of Cenozoic oceanic volcanic rocks as measured by the differentiation index of Thornton and Tuttle (1960). The four basalts and two trachyandesites from Peter I Island conform to the bimodal pattern advocated by Chayes (Figure 11). Martin and Piwinskii (1972) have argued that such a bimodal compositional distribution is characteristic of volcanic rocks formed in nonorogenic settings.

No chemical analyses were made of the gabbroid inclusions in the trachyandesites because of their coarse texture and the wide variations in the estimated modes. Dunne (1946) describes xenoliths from the volcanic rocks of Tristan da Cunha which have mineralogy similar to the Peter I Island inclusions. Lewis (1973) discusses gabbroic blocks within andesites on St. Vincent in the West Indies which also show mineralogical and textural similarities. In both these cases, however, the plagioclases are much more calcic than in the Peter I Island inclusions, which show a range of $A_{n}$ । to $A_{72}$. Most of the Peter I Island inclusions appear to be varieties of gabbro, but some of these rocks may be diorite. The texture and mineralogy of these inclusions, along with the absence of oriented fabrics and strain lamellae, suggest that these rocks formed at modest depths, probably within the oceanic crust or the volcano.

The relative abundances of the several rock types of Peter I Island are important in developing a petrogenetic model. No accurate estimates are possible yet because of poor exposures and limited study. The dredged specimens of Broch (1927) represent a random 


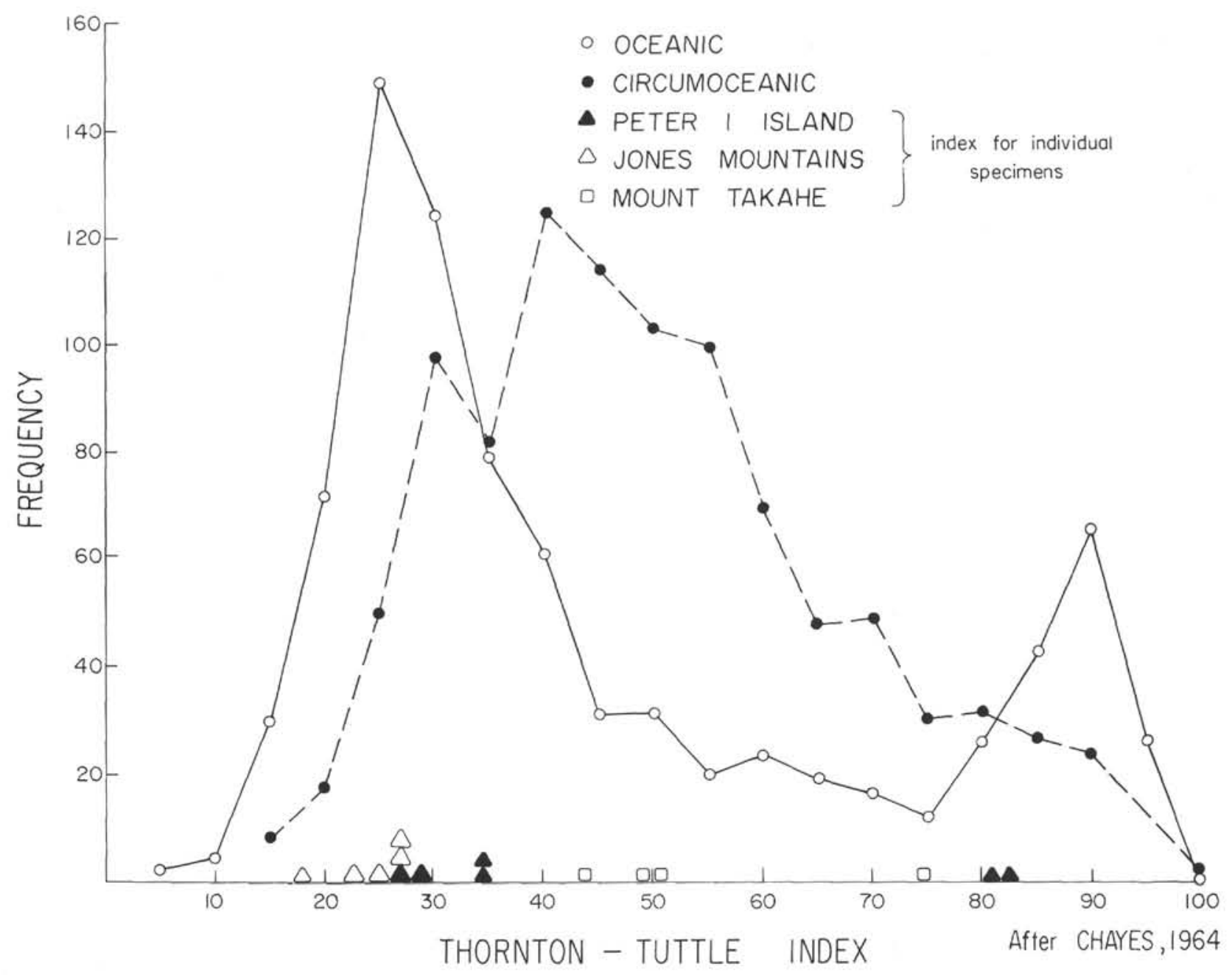

Figure 11. Thornton-Tuttle differentiation indexes ( $\Sigma$ normative $Q$, Or, Ab, Lc, Ne) for volcanic rocks from Peter I Island and two localities in West Antarctica, compared to frequency curves for oceanic and circumoceanic volcanic rocks (see text).

sample and show these weight percentages: (1) basalts-94.5\% (2) andesites-2.7\%, (3) trachyandesites $-0.9 \%$, and (4) inclusion- $-0.1 \%$. The trachyandesites, however, are soft and may well be underrepresented in the dredged collection. In the 1960 collection the weight percentages are (1) basalts $-45 \%$, (2) trachyandesites-44\%, and (3) gabbroid inclusions-11\%; but this collection was deliberately biased in favor of the trachyandesites and inclusions.

\section{SUMMARY}

Peter I Island is an oceanic volcanic island which has had its original form extensively modified by shoreline processes and glacial erosion. A prominent wave-cut platform surrounds the island; with continued erosion its profile will come to resemble a typical guyot. A single whole-rock K-Ar age of $12 \mathrm{~m}$.y. has been obtained on a basalt flow at Cape Ingrid. No historic volcanism has been reported, but the maximum peak elevation measured in 1960 is considerably greater than that found by earlier visitors.
The volcanic rocks of Peter I Island are principally oceanic olivine basalts, with lesser amounts of andesite, trachyandesite, and possibly benmorite and trachyte. All these rocks may represent a single volcanic series, somewhat alkaline in character, but lying mainly in the transition field between the tholeiitic basalt series and the alkali olivine basalt series. Six chemical analyses suggest, but do not establish, a bimodal distribution of volcanic rocks in terms of compositions. The trachyandesites contain coarse-grained gabbro-todiorite inclusions which probably formed within the oceanic crust or the volcano.

\section{ACKNOWLEDGMENTS}

We appreciate the interest and counsel of the late Hisashi Kuno during a time when we were all at the University of Minnesota. Edward Doss, then chief electrician on the U.S.S. Burton Island, aided in the field work on Peter I Island. This work was supported by the National Science Foundation Office of Antarctic Programs. 


\section{REFERENCES}

Anderson, V.H., 1960. The petrography of some rocks from Marie Byrd Land, Antarctica: U.S.N.C.-I.G.Y. Antarctic Glaciol. Data 1958-59, Rept., 825-2, Part VIII, p. 1-27.

Antarctic Report, 1964. Field report 62, Office of Antarctic Programs, National Science Foundation, Washington, D.C.

Broch, O.A., 1927. Gesteine von der Peter I.-Insel, West Antarktis: Auh. Norske Vid. Akad., M.N.K1., no. 9, p. 1-41.

Chayes, F., 1964. A petrographic distinction between Cenozoic volcanics in and around the open oceans: J. Geophys. Res., v. 69, p. 1573-1588.

Craddock, C., Bastien, T.W., and Rutford, R.H., 1964. Geology of the Jones Mountains area. Antarctic Geology: Amsterdam (North Holland Publ. Co.), p. 171-187.

Commander Task Force Thirty Nine, Report of Operations, Second Antarctic Development Project, 1947-1948, Annex IA, p. 1-18.

Debenham, F. (Ed.), 1945. The Voyage of Captain Bellingshausen to the Antarctic Seas 1819-1821: London (Hakluyt Society).

Dubinin, A.I., 1960. $O b$ near Peter I Island: Inf. Bull. Soviet Antarctic Exped., no. 23, p. 81-84.

Dunne, J.C., 1946. Volcanology of the Tristan da Cunha Group: Norwegian Sci. Exped. to Tristan da Cunha 19371938, Results, v. 1, p. 1-145.

Engel, A.E.J., Engel, C.G., and Havens, R.G., 1965. Chemical characteristics of oceanic basalts and the upper mantle: Geol. Soc. Am. Bull., v. 76, p. 719-734.

Fenner, C.N., 1938. Olivine fourchites from Raymond Fosdick Mountains, Antarctica: Geol. Soc. Am., Bull., v. 49 , p. $367-400$.

Holderson, H., 1948. The "Brategg" Expedition: The Norwegian Whaling Gazette, no. 6, p. 220-227.

Holtedahl, O., 1929. On the geology and physiography of some Antarctic and Sub-Antarctic islands: Norwegian Antarctic Exped. 1927-1928-1929, Sci. Results, no. 3, p. 83-88.

Irvine, T.N. and Baragar, W.R.A., 1971. A guide to the chemical classification of the common volcanic rocks; Canadian J. Earth Sci., v. 8, p. 523-548.

Kuno, H., 1962. Frequency distribution of rock types in oceanic orogenic, and kratogenic volcanic associations: Am. Geophy. Un., Geophys. Mono., no. 6, p. 135-139.

1968. Differentiation of basaltic magmas. In Hess, H.H. and Poldervaart, A. (Eds.), Basalts: New York (Interscience), v. 2, p. 623-688.

Kuno, H., Yamasaki, K., Iida, C., and Nagashima, K., 1957. Differentiation of Hawaiian magmas: Jap. J. Geol. Geog., v. 28 , p. $179-218$.

Le Maitre, R.W., 1962. Petrology of volcanic rocks, Gough Island, South Atlantic: Geol. Soc. Am. Bull., v. 73, p. 1309-1340.

Lewis, J.F., 1973. Petrology of the ejected plutonic blocks of the Soufriere volcano, St. Vincent, West Indies: J. Petrol., v. 14 , p. $81-112$.

Macdonald, G.A., 1967. Forms and structures of extrusive basaltic rocks. In Hess, H.H. and Poldervaart, A. (Eds.), Basalts: New York (Interscience), v. 1, p. 1-61.

Macdonald, G.A. and Katsura, T., 1962. Relationship of petrographic suites in Hawaii: Am. Geophy. Un., Geophys. Mono., no. 6, p. 187-195.

1964. Chemical composition of Hawaiian lavas: J. Petrol., v. 5, p. 82-133.

Martin, R.F. and Piwinskii, A.J., 1972. Magmatism and tectonic setting: J. Geophys. Res., v. 77, p. 4966-4975.
Menard, H.W., 1964. Marine geology of the Pacific: New York (McGraw-Hill).

Rittman, A., 1962. Volcanoes and their activity: New York (Interscience).

Shimizu, H., 1964. Glaciological studies in West Antarctica, 1960-1962: Antarctic snow and ice studies, Am. Geophy. Un., Antarctic Res. Ser., v. 2, p. 37-64.

Tobi, A.C., 1963. Plagioclase determination with the aid of the extinction angles in sections normal to (010). A critical evaluation of current albite-Carlsbad charts: Am. J. Sci., v. 261 , p. $157-167$.

Thomas, E., 1957. Chilean Antarctic expeditions, 1955-56: Polar Rec., v. 8, p. 525-527.

Thornton, C.P. and Tuttle, O.F., 1960. Chemistry of igneous rocks. I. differentiation index: Am. J. Sci., v. 258, p. 664684.

Tilley, C.E. and Muir, I.D., 1964. Intermediate members of the oceanic basalt-trachyte association: Geol. Foreningens Stockholm Forhandl., v. 85, p. 434-443.

Tyrell, G.W., 1945. Report on rocks from West Antarctica and the Scotia Arc: Discovery Rept., v. 23, p. 37-102.

United States Navy Hydrographic Office, 1960. Sailing directions for Antarctica: H.O. Publ. no. 27: Washington (U.S. Government Printing Office).

Wilkinson, J.F.G., 1967. The petrography of basaltic rocks. In Hess, H.H. and Poldervaart, A. (Eds.), Basalts, New York (Interscience), v. 1, p. 163-214.

Wilshire, H.C. and Binns, R.A., 1961. Basic and ultrabasic xenoliths from volcanic rocks of New South Wales: J. Petrol., v. 2, p. 185-208.

\section{APPENDIX \\ Peter 1 Island Rock Specimens, Collected by Craddock at Norvegia Bay, 29 February 1960}

1. Beach cobble of olivine basalt.

2. Slightly vesicular basalt, from flow.

3. Slightly vesicular olivine basalt with inclusion of granular olivine, from flow.

4. Vesicular, glassy olivine basalt with irridescent surface, from flow.

5. Vesicular olivine basalt, from flow.

6. Beach cobble of olivine basalt with elongated vesicles.

7. Slightly vesicular olivine basalt, from dike $15 \mathrm{in}$. wide.

8. Slightly vesicular olivine basalt, from flow.

9. Talus clast of vesicular olivine basalt, altered to reddish-brown.

10. Talus clast of vesicular basalt, altered to grayish-red.

11. Talus clast of vesicular basalt.

12. Talus clast of vesicular basalt, probably formed as bulbous squeeze-up.

13. Beach cobble of porphyritic aphanite, probably trachyandesite.

14. Trachyandesite, from flow.

15. Beach boulder of vesicular olivine basalt, altered to grayish-red, with inclusion of glassy trachyandesite.

16. Trachyandesite (?) with small gabbroid inclusion, from flow.

17. Trachyandesite (?), from flow.

18. Beach boulder of trachyandesite (?) with gabbroid inclusions.

19. Trachyandesite with gabbroid inclusion, from flow.

20. Trachyandesite with gabbroid inclusions, from flow.

21. Trachyandesite (?) with gabbroid inclusion, from flow.

22. Trachyandesite (?) with gabbroid inclusion, from flow.

23. Trachyandesite (?) with gabbroid inclusion, from flow.

24. Beach boulder of trachyandesite with gabbroid inclusion.

25. Beach cobble of trachyandesite (?) with gabbroid inclusion.

26. Beach cobble of trachyandesite (?) with gabbroid inclusion.

27. Glassy trachyandesite (?), from flow.

28. Trachyandesite (?) with gabbroid inclusions, from flow.

29. Beach cobble of trachyandesite (?) with gabbroid inclusion. 